\title{
Is There Discrimination Among Brazilian Lawyers? A Random-Effects Approach*
}

\section{Existe Discriminação entre Advogados Brasileiros? Uma Abordagem de Efeitos Aleatórios}

Paulo R. A. Loureiro** Adolfo Sachsida***

Tito Belchior S. Moreira****

\begin{abstract}
The paper investigates the existence of discrimination amongst lawyers in the private sector of the Brazilian labor market. Using the random-effects approach to estimate earnings equations, combined with the Oaxaca-Ransom (1994, 1999) decomposition methodology, we test the hypothesis that wage differentials amongst lawyers are mostly due to gender discrimination. The econometric evidence shows that with the addition of the specific effects of time in the model, the unexplained share of the Oaxaca-Ransom (1994, 1999) decomposition (attributed to discrimination) is reduced over time comparatively to the share attributed to individual characteristics (endowments). In this context, our results indicate that there is gender discrimination amongst lawyers in Brazil.
\end{abstract}

Keywords: Wage differentials. Gender discrimination. Labor market for lawyers.

Resumo: Este artigo investiga a existência de discriminação entre advogados no setor privado do mercado de trabalho brasileiro. Usando a abordagem de feitos aleatórios para estimar as equações de ganhos, combinado com a metodologia de decomposição de Oaxaca-Ransom (1994, 1999), testamos a hipótese de que diferenciais de salários entre advogados são decorrentes principalmente de discriminação por gênero. A evidencia econometrica mostra que com a inclusão no modelo do efeito específico do tempo, uma parte não explicada da decomposição de Oaxaca-Ransom (1994, 1999) atribuído à discriminação é reduzida ao longo do tempo comparativamente à parte atribuída às características individuais (dotações). Nesse contexto, nossos resultados indicam que existe discriminação por gênero entre advogados no Brasil.

Palavras-chave: Diferenciais de salários. Discriminação por gênero. Mercado de trabalho para advogados.

JEL Classification: J71; J31.

\footnotetext{
* We are indebted to two anonymous referees for valuable comments. We also thank Francisco Galrão Carneiro for helpful suggestions.

** Professor da Universidade de Brasília (UnB). E-mail: pauloloureiro@unb.br

*** Pesquisador do Instituto de Pesquisa Econômica Aplicada (Ipea). E-mail: sachsida@hotmail.com

**** Professor da Universidade Católica de Brasília. E-mail: tito@pos.ucb.br
} 


\section{Introduction}

Recent transformations in the labor market indicate growth in the rate of women's participation in various positions that were, until recently, exclusively held by men. One of these is the law profession (ROSEN, 1992). There is evidence that the number of female lawyers has grown consistently over the last thirty years in several countries (INTERNATIONAL LABOUR ORGANIZATION, 2001). Apparently, the reasons for a higher rate of participation by women in the law profession are the same that explain the increase in the number of women in other professions. Some of these reasons include the decrease in the number of children couples have, reducing the need for women to stay at home and take care of the children, an increase in attendance and performance by women at colleges and universities, and the need to increase family income.

In spite of the increase in female participation rates in the labor market, the wages of females are lower than men's for similar occupations, in several professions (INTERNATIONAL LABOUR ORGANIZATION, 2001). The existence of wage differentials that persists among equally productive workers is an issue that has been exhaustively studied in the literature and indicates the practice of discrimination (ARROW, 1972, 1973; BECKER, 1957; PHELPS, 1972). For the specific case of lawyers, this phenomenon has been studied for industrialized countries by several authors (BIDDLE; HAMERMESH, 1998; HUANG, 1997; PASHIGIAN, 1977; ROSEN, 1992; SPURR, 1990), but there is little or no evidence for developing countries. As argued by Bashaw e Heywood (2001), the analysis of wage differentials for specific professions helps to control characteristics such as specialized education, on-the-job training, and other determining factors for salaries that are generally neglected in estimates based on cross section data that aggregate several professions. Also, traditionally, specific analyses by profession are aggregated to a vaster literature, confirming such salary differentials in the labor market.

Loureiro (2003) makes a review of the main of the models of discrimination and examines the possible sources of racial and gender discrimination in the labor market. From a theoretical point of view, the model shows that the discriminatory behavior of the employers is inversely related to the profits of the firms. The models of statistical discrimination assume that the creditor or employers don't have complete information on the individuals. These models use the characteristics of the groups that suffer discrimination, as race or its sex, to reduce the value of the credit or the wage.

Becker (1957) defines discrimination as a situation where an economic agent is prepared to incur a cost in order to refrain from an economic transaction, or from entering into an economic contract, with someone who is characterized by traits other than his/her own with respect to race or sex. Becker demonstrates that such behavior, in purely analytical terms, acts as a "tax wedge" between social and private economic rates of return. The explanations is that the discriminating agent behaves as if the price of the good or service 
purchased from the discriminated agent were higher than the price a actually paid, and the selling price to the discriminated agent is lower than the price actually obtained. Discrimination thus trends to be economically detrimental not only to those who are discriminated against, but also to those who practice discrimination.

Statistical discrimination is a theory of why minority groups are paid less when hired. The theory is roughly that managers, who are of one type (say, white), are more culturally attuned to the applicants of their own type than to applicants of another type (say, black), and therefore they have a better measure of the likely productivity of the applicants of their own type. There is uncertainty in the manager's predictions about blacks and probably of whites too, but more uncertainty for blacks. Because the managers are risk averse they bid more for a white applicant of a given apparent productivity than for a black one, since their measure of the white's productivity is better. This theory predicts that white managers would offer black applicants lower starting wages than whites of the same apparent ability, even if the manager is not prejudiced against the blacks. The issue is addressed, for example, by Arrow (1973) anda Phelps (1972).

In this paper, we investigate the situation of women in the labor market for lawyers in Brazil, a country that has undergone significant changes in its labor market, including an increase in the rate of participation for several occupations. In aggregate terms, the rate of female participation in the Brazilian labor market has grown from $36.9 \%$ in 1985 to nearly $53.4 \%$ in $1995 .{ }^{1}$ The data for years of schooling indicate that a higher rate of female participation is becoming evident for those with more years of schooling, representing $69 \%$ for women between 11 and 14 years of schooling, and $82.3 \%$ for women with more than 15 years of schooling (BRUSCHINI, 2000). For the specific case of lawyers, data obtained from the Annual Social Information Listings (RAIS) indicate that the number of women working in this area increased nearly 12\% between 1997 and 2000, which has augmented the proportion of women in total number of lawyers from $40.2 \%$ to $43.3 \%$ over a period of four years. ${ }^{2}$

The main motivation to analyze the existence of discrimination amongst lawyers is related to low cost of transaction for the lawyers to restrain the discrimination by gender among them. Of course, the lawyers would access the justice system with lower cost of transaction than any other profession. If this sense, if there exist discrimination amongst lawyers by gender, it is probably that there exist discrimination in others labor marker segments as well.

We have thus sought to verify the existence of wage discrimination by gender in the Brazilian labor market for lawyers and, in a positive case, what the main determinants are. Towards this objective, we have used a pseudo-panel constructed from data for the 1992-99 period to estimate the traditional income

This information was calculated by authors based on PNAD-IBGE.

Saboia and Tolipan (1985) and Negri, Castro, Souza and Arbache (2001) point out methodological differences between the database of RAIS and PNAD. 
equations and detect the salary differentials among lawyers in Brazil. Later, we apply the Oaxaca-Ransom (1994, 1999) methodology to decompose the wage differentials and investigate the existence of discrimination among lawyers.

The article is structured as follows. After the introduction, Section 2 presents a brief review of the literature analyzing the labor market for lawyers in several countries. Section 3 discusses some specific aspects of this market in Brazil, while Section 4 presents the data analysis methodology in a pseudo-panel and the estimated results, and Section 5 describes the methodology and presents the results of the decomposition analysis for the Oaxaca-Ransom $(1994,1999)$ wage differentials. Lastly, Section 6 outlines the conclusions that point to the existence of statistical discrimination against female lawyers.

\section{Review of the Literature}

Most studies of the labor market for lawyers seek to confirm whether or not there is wage discrimination and occupational mobility patterns for the profession. Sauer (1998), conducted an occupational mobility analysis for lawyers that revealed the existence of a self-selection mechanism when lawyers choose an area of activity, due to specific acquired capacities. This means that lawyers with less training and little experience tend to remain in the least lucrative areas of the profession (small firms), while those with more training and experience tend to remain in the so-called elite sectors (large private law firms).

Biddle and Hamermesh (1998) investigated the existence of discrimination in the labor market for lawyers based on lawyer appearance. The authors pointed out that the great majority of empirical studies on discrimination are based on inadequate productivity parameters, and that very few studies are able to adequately establish the existence of wage differentials and to identify their true sources. Thus, with a database comprised of information collected on law school students, the authors demonstrated that better dressed lawyers receive higher salaries. The reasons for this would be the existence of employer discrimination, discrimination by clients, and/or discrimination by judges and juries, who all attribute improved productivity to better appearance.

On the other hand, Laband and Lentz (1993) investigated the existence of gender discrimination in American law firms. Using a series of qualitative variables (such as the reputation of the law school the person graduated from, marital status, time spent with family and in religious activities, etc.), the study did not identify tangible discrimination between men and women (neither in terms of wages, nor in terms of promotions). However, the authors noticed the occurrence of gender discrimination in terms of job dissatisfaction, for they noticed that job changes among female lawyers were more frequent than among male lawyers. 
In another study, Wood, Corcoran and Courant (1993) divided American lawyers in two groups: a) those who had graduated some time ago; e b) recent graduates. Their results indicated that the human capital of male and female lawyers was virtually identical within the same group, but differed between group "a" and "b", and that there was a mean wage difference of $15 \%$ favoring the males in both groups. Rosen (1992) also detected a substantial wage difference among American lawyers, most of this difference being attributed to individual personal characteristics, such as experience and hours worked. The rest, however, was attributed to several random factors and to the presence of discrimination.

Other evidence of discrimination in the law profession was found by Spurr (1990). The author utilized regression analysis and maximum-likelihood estimates of a probability model for the offering of legal services and found that women were $50 \%$ less prone than men in becoming a partner of a large law firm, in spite of there being no significant differences among them in terms of academic distinction, the quality of the law schools attended or their productivity levels.

Lastly, in a study of the Canadian economy, Stager and Foot (1989b) showed that the gender wage differential among lawyers in 1970 was $50.7 \%$ in favor of the men, diminishing to $42.2 \%$ in 1980 . According to the authors, this wage differential should be attributed to the presence of discrimination. Besides, the rapid growth in the number of Canadian lawyers during the 70s had an unexpected lesser impact on the female lawyers' wages than it did on the males', in spite of there being a proportionately higher number of female lawyers. The occurrence of a higher supply of legal services during the 1970-80 period was the justification offered by Foot and Stager (1989a) to explain these wage movements.

\section{Some Specific Facts of the Labor Market for Lawyers in Brazil}

In order to analyze the labor market for Brazilian lawyers, we turned to data offered by the National Home Sampling Survey (PNAD), conducted by the Brazilian Geography and Statistics Institute (IBGE) for the 1992 to 1999 period. The sample used comprised 389 lawyers (212 men and 177 women), all from the private sector. ${ }^{3}$ Table 1 summarizes the mean wages in natural logarithm for the period (except for 1994, when the PNAD was not conducted). According to the information available, if may be inferred that, in 1992, the wage differential between male and female lawyers was $18.6 \%$ in favor of the men, increasing to $23.1 \%$ in 1999 . During this period, the wage differential reached a mean of 0.183 (in natural algorithm), favoring men, or that the female lawyers received, on average, wages that were $20.1 \%$ lower than those of male lawyers. ${ }^{4}$

3 It must be pointed out that this is not a small number of observations. Brown, Fakhfakh and Sessions (1999) used a sample of 127 individuals for 11 years and the Spurr (1990) study used two samples, one of which contained 293 individuals for 8 years.

4 See some paper about discrimination for comparing with the results presented in this section: Barros et al. (2001), Kassouf (1998), Leme and Wajnman (2000) and Ometto, Hoffman and Alves (1999). 
Table 1 - Real mean wages and legal services offerings (\%) of lawyers in the private labor market (1992-1999)

Men

\begin{tabular}{ccccc} 
Year & Wages* & $\begin{array}{c}\text { Legal } \\
\text { Service } \\
\text { Offering (\%) }\end{array}$ & Wages* & $\begin{array}{c}\text { Legal } \\
\text { Service } \\
\text { Offering (\%) }\end{array}$ \\
\hline 1992 & 7.849 & 63.2 & 7.678 & 36.8 \\
1993 & 8.132 & 66.3 & 8.120 & 33.7 \\
1995 & 8.506 & 68.6 & 8.304 & 31.4 \\
1996 & 8.562 & 64.7 & 8.349 & 35.3 \\
1997 & 8.562 & 65.9 & 8.420 & 34.1 \\
1998 & 8.526 & 63.8 & 8.200 & 36.2 \\
1999 & 8.435 & 62.0 & 8.227 & 38.0 \\
Mean & 8.368 & 64.9 & 8.185 & 35.1 \\
\hline
\end{tabular}

Source: Developed by the authors from PNAD's.

Note: * Wages in natural algorithm.

Table 2 compares men's and women's wages by age group. For the Age 1 group (24 to 32 years), the wage differential between men and women is, on average, $30 \%$ in favor of men. For the Age 2 group (33 to 41 years), the average differential is $22 \%$. For the Age 3 group (42 to 50 years), the average differential dropped to $2.4 \%$. Since the wage differential diminishes at higher ages, it may speculated that part of this differential is due to an information problem in the labor market, exemplifying so-called statistical discrimination (ARROW, 1973; CAIN, 1986; PHELPS, 1972).

Table 2 - Real wages* for lawyers by sex and age group in the private labor market (1992-1999)

\begin{tabular}{ccccccc}
\hline & \multicolumn{2}{c}{ Age 1 } & \multicolumn{2}{c}{ Age 2 } & \multicolumn{2}{c}{ Age 3 } \\
Year & Men & Women & Men & Women & Men & Women \\
\hline 1992 & 7.831 & 7.809 & 7.660 & 7.627 & 8.124 & 7.894 \\
1993 & 8.244 & 7.982 & 8.521 & 8.182 & 8.280 & 7.248 \\
1995 & 8.232 & 7.796 & 8.441 & 8.035 & 8.618 & 8.787 \\
1996 & 8.065 & 7.945 & 8.758 & 8.433 & 8.577 & 8.674 \\
1997 & 8.250 & 7.674 & 8.683 & 8.362 & 8.802 & 8.593 \\
1998 & 8.188 & 7.772 & 8.188 & 7.772 & 8.489 & 8.876 \\
1999 & 7.878 & 7.871 & 7.923 & 8.374 & 7.859 & 8.511 \\
Mean & 8.098 & 7.836 & 8.311 & 8.112 & 8.393 & 8.369 \\
\hline
\end{tabular}

Source: Developed by the authors from PNAD's.

Note: * Wages in natural algorithm. 
Table 3 shows the variables to be used in the wage equation to be estimated in the next section. Observing the variable for male lawyers in age group 1, the log of the monthly hour mean wage (Lnw) is 8.098 (which is equal to a monthly average salary of $R \$ 3287.89$ ), as compared to 7.836 for female lawyers (or an average monthly salary of $R \$ 2530.06$ ). In terms of experience, men have nearly 5.69 years and women 5.62 years.

Table 3 - Descriptive statistics for mean and standard deviation for lawyers: private sector (1992-1999)

\section{Age 1 Age 2 Age 3}

\begin{tabular}{ccccccc} 
Variables* & Men & Women & Men & Women & Men & Women \\
\hline Lnw & 8.098 & 7.836 & 8.311 & 8.112 & 8.393 & 8.369 \\
& $(0.165)$ & $(0.098)$ & $(0.376)$ & $(0.292)$ & $(0.300)$ & $(0.545)$ \\
Exp & 5.69 & 5.62 & 15.29 & 15.22 & 24.18 & 23.70 \\
& $(2.53)$ & $(2.60)$ & $(2.95)$ & $(2.65)$ & $(2.68)$ & $(2.73)$ \\
Exp2 & 38.64 & 38.26 & 242.18 & 238.35 & 591.7 & 569.04 \\
& $(31.22)$ & $(32.05)$ & $(88.91)$ & $(79.42)$ & $(133.9)$ & $(131.49)$ \\
Marriage & 0.31 & 0.67 & 0.67 & 0.43 & 0.82 & 0.63 \\
& $(0.47)$ & $(0.47)$ & $(0.47)$ & $(0.50)$ & $(0.39)$ & $(0.49)$ \\
Age & 27.57 & 27.56 & 37.08 & 37.16 & 46.05 & 45.70 \\
& $(2.48)$ & $(2.60)$ & $(2.79)$ & $(2.63)$ & $(2.52)$ & $(2.73)$ \\
\hline
\end{tabular}

Source: Developed by the authors from PNAD's.

"Lnw is the natural logarithm of the monthly average salary, deflated by the CPI issued by FGV/RJ; exp is the average number of years of experience; exp2 is the square of the average number of years of experience; Marriage is the dummy for marital statusl (married $=1$, not married $=0$ ); Age is average age in years. The values in parenthesis are the respective standard deviations.

\section{Estimates Using Pseudo-Panel Data}

Panel data may have group effects, time effects, or both. These effects are either fixed effect or random effect. A fixed effect model assumes differences in intercepts across groups or time periods, whereas a random effect model explores differences in error variances. In this section, we present earnings analysis for lawyers in Brazil using the foxed effects methodology for a pseudo-panel.

The econometric procedures adopted in this section follow the methodology proposed by Deaton (1985). In other words, the economic relations estimate is based on the cohort average and not on individual observations. Besides, cohorts are constructed so as to include all individuals of the same sex (either 
male or female) in a specific age group. Since the age cohort is well defined and may be easily identified in the data, Deaton (1985) argues that such a pseudopanel would not be subject to the friction problem that affects the genuine panel, and may also be available for longer periods of time. ${ }^{5}$

The use of the pseudo-panel analysis in economic applications offers several advantages not offered by traditional econometric methods. The pseudo-panel data are normally used in individual activity analyses in the labor market, offering the researcher a large number of data points. This characteristic has the advantage of increasing the degrees of freedom, reducing co-linearity among the explicative variables, increasing efficiency and, as a result, the econometric estimates. Also, the panel data models allow the researcher to analyze a great number of variables that are not directly observable, and that cannot be investigated using cross-section or time series methodologies (HSIAO, 1986). As usual, we stand out that in our study, the database is polled.

The earnings equation to be estimated is as follows:

$$
y_{i t}=\alpha_{i}+\beta^{\prime} x_{i t}+\lambda_{t}+e_{i t} \quad(i=1,2, \ldots . . n ; t=1, \ldots ., T)
$$

where $y_{i t}$ is a wage vector, $x_{i}$ is a individual characteristics vector, the underscored $t$ measures time and $n$ is the number of individuals, and $e_{i t}$ is the error component that varies among individuals and over time. A specific formulation of this equation, that controls both groups by non-observed heterogeneity $\left(\alpha_{i}\right)$ and specific time effects $\left(\lambda_{t}\right)$, may be estimated with the fixed-effect technique. The $\alpha_{i}$ intercepts vary solely from individual to individual and capture all the different characteristics among individuals over time. It is recognized that there are several non-observable factors that influence individual gains and/or losses, such as: intelligence, motivation, and dedication that are difficult to measure and for which there are no close substitutes.

The estimated earnings equation follows the procedure that has become habitual in the literature, in which wages are displayed as a function of gender, experience, age, race, marital status, ${ }^{6}$ etc. Admitting discrimination by gender, it is expected that the degree of discrimination decrease with the time. This statement is addressed, for example, by Arrow (1973), Arrow (1998) and Phelps (1972).

Three cuts were made to break down the sample into the following classes: Age 1, corresponding to individuals in the 24 to 32 age group; Age 2, corresponding to the 33 to 41 age group; and Age 3 that covers the 42 to 50 age group. ${ }^{7}$ In this sense, when it is introduced this fixed effect of the ages, the earn resulting of discrimination are not biased. However, as we will see, the Hausman test indicates that the random effect is more appropriated. The estimated results appear in Table 4.

More details on the methodology proposed by Deaton (1985) and that was used in this study to construct the series and the econometric estimates, may be found in Baltagi (1995, p. 176-77).

6 Such variables are in accordance with several studies on this theme, among which are: Neumark (1998), Laband and Lentz (1993), Wood and Corcoran (1993) and Cotton (1988).

Said methodological procedure is validated by Deaton (1985).
} 
The Hausman (1978) test was performed to verify which model, the fixedeffect or the random effect, should be used. The results signaled towards the acceptance of the random-effects model, with a value of the chi-square statistic of 0.29 and a probability of 0.99 for the men equation and with a value of the chi-square statistic of 1.52 and a probability of 0.822 for the women equation. Therefore, we concluded that the random effects model was the most appropriate for the discrimination study of the labor market for Brazilian lawyers. ${ }^{8}$ In the appendix, we presented all the estimated equations in tables M1 to M4 and we presented the test of Hausman in tables M5 and M6 as well.

Table 4 - Wage equations with individual effects and individual effects and specific in time in the labor market for lawyers, private sector (1992-1999)*

\begin{tabular}{|c|c|c|c|c|}
\hline Variables & $\begin{array}{c}\text { Men: } \\
\text { Individual } \\
\text { Effects and } \\
\text { Time Effects } \\
\text { (Model 1) }\end{array}$ & $\begin{array}{c}\text { Men: } \\
\text { Individual } \\
\text { Effects } \\
\text { (Model 2) }\end{array}$ & $\begin{array}{l}\text { Women: } \\
\text { Individual } \\
\text { Effects and } \\
\text { Time Effects } \\
\text { (Model 3) }\end{array}$ & $\begin{array}{l}\text { Women: } \\
\text { Individual } \\
\text { Effects } \\
\text { (Model 4) }\end{array}$ \\
\hline Constant & $5.628 * *(0.110)$ & $6.122 * *(0.092)$ & $5.693 *(0.126)$ & $6.204 *(0.103)$ \\
\hline Exp & $0.067 * *(0.011)$ & $0.069 * *(0.111)$ & $0.046 *(0.011)$ & $0.043 * *(0.011)$ \\
\hline Exp2 & $-0.001 * *(<0.001)$ & $-0.001 * *(<0.001)$ & $-0.001(<0.001)$ & $-0.001(<0.001)$ \\
\hline Marriage & $0.064 \quad(0.050)$ & $0.049(0.052)$ & $0.010 \quad(0.052)$ & $0.023 \quad(0.054)$ \\
\hline Race & $0.170 *(0.053)$ & $0.177 * *(0.055)$ & $0.109 \quad(0.066)$ & $0.144^{*} \quad(0.068)$ \\
\hline Year 93 & $0.218^{*} \quad(0.089)$ & - & $0.441 * *(0.110)$ & - \\
\hline Year 95 & $0.601 * *(0.086)$ & - & $0.632 * *(0.108)$ & - \\
\hline Year 96 & $0.614 * *(0.086)$ & - & $0.652 *(0.103)$ & - \\
\hline Year 97 & $0.657 * *(0.083)$ & - & $0.728 *(0.101)$ & - \\
\hline Year 98 & $0.632 * *(0.083)$ & - & $0.529 * *(0.099)$ & - \\
\hline Year 99 & $0.521 * *(0.084)$ & - & $0.556 *(0.101)$ & - \\
\hline
\end{tabular}

Source: Developed by the authors from PNAD's.

Note: the values in parenthesis represent the standard deviations of the variables. $\left(^{*}\right)$ level of significance at $5 \%$ and $(* *)$ level of significance at $1 \%$.

8 The Hausman specification test compares the fixed versus random effects under the null hypothesis that the individual effects are uncorrelated with the other regressors in the model (Hausman 1978). If correlated ( $\mathrm{Ho}$ is rejected), a random effect model produces biased estimators, violating one of the Gauss-Markov assumptions; so a fixed effect model is preferred. 
From the estimated results, it may be observed that the variables obtained signs that agreed with those expected in all models. The interpretation of the estimated parameters must be done based on the rates of return, for the function is in log-linear format. For example, the estimated coefficients indicate that the return to experience rates for female lawyers were lower than the returns to experience rates for male lawyers: $4.6 \%$ as opposed to $6.7 \%$ (model 3 as opposed to model 1 ), and $4.3 \%$ as opposed to $6.9 \%$ (model 4 as opposed to model 2). The economic relevance of the experience variable is related to the fact that said variable is able to detect the influence of human capital on the returns obtained by lawyers. Overall, the results of the equations estimated by the random-effects method based on individual effects (models 2 and 4) are as expressive as those based on the individual and time effects (models 1 and 3). We stand out that, only the variable marriage is not significant in all models. Furthermore, the variable exp2 is not significant for women in according to models 3 and 4. The variables Year 93 to Year 99 are dummy variables (all significant) that represent the time effect.

\section{The Oaxaca and Ransom (1994) Decomposition}

In order to investigate the existence of discrimination by gender in the labor market for lawyers, we have adopted the Cotton (1988) and Oaxaca and Ransom (1994) methods, and calculated the magnitude of wage discrimination as follows:

$$
\overline{\ln w_{m}}-\overline{\ln w_{f}}=\beta *\left(\bar{X}_{m}-\bar{X}_{f}\right)^{\prime}+\bar{X}_{m}^{\prime}\left(\hat{\beta}_{m}-\beta *\right)+\bar{X}_{f}^{\prime}\left(\beta^{*-\hat{\beta}_{f}}\right)
$$

where $\operatorname{lnw}_{\mathrm{m}}$ is the wage logarithm for men, $\ln _{\mathrm{f}}$ is the wage logarithm for women, $\hat{\beta}_{m}$ is the estimated coefficient vector for male workers, $\hat{\beta}_{f}$ is the estimated coefficient vector for female workers, $\bar{X}_{m}^{\prime}$ is the average characteristics vector for men, $\bar{X}_{\mathrm{f}}^{\prime}$ is the average characteristics vector for women and $\beta *$ is the vector that is constructed from the coefficients that determine wages in the absence of discrimination. ${ }^{9}$

Equation (2) is the average difference of the natural algorithms of the male and female wages. The expression $\beta *\left(\bar{X}_{m}-\bar{X}_{f}\right)$ is the portion of the differential attributed to the difference in productive characteristics between men and women (known as the endowment effect). The expression $\bar{X}_{m}^{\prime}\left(\hat{\beta}_{m}-\beta^{*}\right)$ is the portion of the wage differential attributed to men, while $\bar{X}_{f}^{\prime}\left(\beta^{*}-\hat{\beta}_{f}\right)$ is the portion of the wage differential attributed to women. Together, the second and third terms represent the conventional discrimination estimates in the income differential studies (known as the coefficient effect). In the absence of discrimination, the differential is explained by human capital and

9 Cotton (1988) shows that, in the absence of discrimination, the only reason for wage differences to occur would be the existence of differences in productivity characteristics. Therefore, in the absence of discrimination, the wage structure is assumed to be: $\beta^{*}=\beta_{\mathrm{m}}=\beta_{\mathrm{f}}$. 
other measurable variables. The result of the difference between the first term on the right hand side of the equation (2) minus the sum of the other two terms (second and third) is the magnitude of wage discrimination.

The $\beta^{*}$ estimator used in this paper is defined as: $\beta^{*}=p_{m} \hat{\beta}_{m}-p_{f} \hat{\beta}_{f}$, where $\mathrm{p}_{\mathrm{m}}$ and $\mathrm{p}_{\mathrm{f}}$ are the proportions of male and female labor in the labor market. This supposition is simplified by specifying $\beta^{*}$ as a linear function of $\beta \mathrm{m}$ and $\beta \mathrm{f}$, which are the respective wage structures of both groups of workers. This supposition may be made operational by pondering the wage structure of both groups of workers according to the proportions of employed labor (COTTON, 1988).

Table 5 shows the mean wage difference in natural logarithm between male and female lawyers in the private labor market. The mean wage differential, in natural algorithm, between male and female lawyers is 0.161. This Table also shows the discrimination based on individual effects plus other explicative variables based on Models 2 and 4 presented in Table 4 and the discrimination based on individual effects and time effects plus other explicative based on Models 1 and 3 presented in Table 4 as well. It may be observed that, in models 1 and 3, in which the specific time effects are added, the variations derived from the unexplained portion of the Oaxaca-Ransom (1994) decomposition (attributed to discrimination) are lower in relation to the explained portion of the decomposition (attributed to endowments) as compared with models 2 and 4 . Therefore, the wage differential between lawyers diminishes over time. This behavior shows that there is a link between empirical estimators for the determining of wages and the statistical discrimination model.

Noticing that the Oaxaca-Ransom Decomposition is calculated based on equation (2), where $\hat{\beta}_{m}$ is the estimated coefficient of the individual characteristics of male (man) from Table 4 and $\hat{\beta}_{f}$ is the estimated coefficient of the individual characteristics of female (woman) also from Table 4.

Table 5 - Oaxaca-Ransom decomposition of lawyer wages by gender in the private labor market (1992-1999)

\begin{tabular}{ll}
\hline Specifications & Man/Woman \\
\hline Lnw & \\
Men & 8.267 \\
Women & 8.106 \\
Discrimination based on individual effects (plus other explicative variables) \\
\hline
\end{tabular}

Models 2 and 4

$\%$ Attributed to discrimination

$61 \%$

$\%$ Attributed to endowments

$39 \%$

Discrimination based on individual effects and time effects (plus other explicative variables)

Models 1 and 3

$\%$ Attributed to discrimination $\quad 59 \%$

$\%$ Attributed to endowments $\quad 41 \%$

Source: Developed by the authors from PNAD's.

LOUREIRO, P. R. A.; SACHSIDA, A.; MOREIRA, T. B. S. Is there discrimination among Brazilian lawyers? 
Based on the results obtained, it may be stated that there is discrimination by gender among Brazilian lawyers. Also, it seems that the origins of said discrimination are not to be found in the preference of agents as suggested by Becker (1957); on the contrary: discrimination seems arise from informational problems in the market. This means as time passes and the employer is better informed as to the quality of work of female lawyers, discrimination tends to diminish. Such form of discrimination may be interpreted as empirical evidence of the occurrence of statistical discrimination (CAIN, 1986).

\section{Final Considerations}

In this article we utilized an analysis methodology of data grouped in a pseudo-panel to estimate an earnings equation for men and women in the law profession in Brazil. After the estimation of the earnings equation, the OaxacaRansom (1994, 1999) decomposition analysis was applied to investigate the existence of discrimination between male and female lawyers. The study was conducted based on micro data obtained from the domestic sampling surveys (PNADs) for the 1992 to 1999 period. The earnings equation was estimated with random effects.

Our results show that male lawyers earn, on average, $20.1 \%$ more than female lawyers, and that in spite of the fact that part of this salary differential results from differences in individual abilities, most of it comes from discrimination. Some international experiences corroborate with our empirical finds as follow.

Wood, Corcoran and Courant (1993) define two cuts made to break down the sample into the following groups: those who had graduated some time ago and recent graduates. Their results indicated that the human capital of male and female lawyers was virtually identical within the same group, but differed between the groups, and that there was a mean wage difference of $15 \%$ favoring the males in both groups. In this sense, these results corroborate with our empirical finds since there exists gender discrimination in favor of male.

Laband and Lentz (1993) also noticed the occurrence of gender discrimination in American law firms. They pointed out discrimination in terms of job dissatisfaction as job changes among female lawyers were more frequent than among male lawyers. The results of Foot and Stager (1989b) showed that the gender wage differential among lawyers in 1970 was $50.7 \%$ in favor of the men, diminishing to $42.2 \%$ in 1980 .

Our results also show that there seems to be evidence that the Brazilian labor market for lawyers is discriminated against in statistical terms. In other words, a great part of the wage differential between males and females does not come from the pleasure employers may feel in discriminating, but from an informational problem. Therefore, over time, as employers become more informed about male and female lawyers, the wage differential is then substantially reduced. 
As mentioned before, our results show that the wage differential between lawyers diminishes over time. According to Sauer (1998), lawyers with less training and little experience tend to remain in the least lucrative areas of the profession, while those with more training and experience tend to remain in the so-called elite sectors. I this sense, the experience and the age are important factors to explain the salary differential. If there is a strong correlation (positive) between age and experience, our results are in the same direction the Sauer (1998). Comparatively, the wage of female tend to approach of the wage of male since that her becomes more experience over time.

\section{References}

ARROW, K. J. The models of job discrimination. In: PASCAL, A. (Ed.). Racial discrimination in economic life. Lexington, KY: Lexington Books, 1972. p. 83-102.

. The theory of discrimination. In: REES, A.; ASHENFELTER, O. (Ed.). Discrimination in labour markets. Princeton: Princeton University Press, 1973.

. What has economics to say about racial discrimination? The Journal of Economic Perspectives, v. 12, n. 2, p. 91-100, 1998.

BALTAGI, B. H. Econometric analysis of panel data. London: John Willey E Sons, 1995.

BARROS, R. P. et al. Inserção no mercado de trabalho: diferenças por sexo e conseqüências sobre o bem-estar. Rio de Janeiro: IPEA, 2001. (Texto para Discussão, n. 796).

BASHAW, D. J.; HEYWOOD, J. S. Gender earnings gap for U.S. physicians: has equality been achieved? Labour, v. 15, p. 371-391, 2001.

BECKER, G. The economics of discrimination. Chicago: University of Chicago Press, 1957.

BIDDLE, J. E.; HAMERMESH, D. S.Beauty, productivity, and discrimination: lawyers' looks and lucre. Journal of Labor Economics, v. 16, n. 1, p. 172-201, Jan. 1998.

BROWN, S.; FAKHFAKH, F.; SESSIONS, J. Absenteeism and employee sharing: an empirical analysis based on french panel data, 1981-1991. Industrial and Labor Relations Review, v. 52, n. 2, p. 234-251, 1999.

BRUSCHINI, C. Brasil: la calidad del empleo de las mujeres: continuidades y cambios. In: VALENZUELA, M. E.; REINECKE, G. (Ed.). Más y mejores empleos para las mujeres? La experiencia de los países del Mercosur y Chile. Chile: Organização Internacional do Trabalho,. 2000.

CAIN, G. The economic analysis of labor market discrimination: a survey. In: ASHENFELTER, O.; LAYARD, R. (Ed.). Handbook of Labor Economics. Amsterdam: Elsevier, 1986. v. 1.

COTTON, J. On the decomposition of wage differentials. The Review of Economics and Statistics, v. 70, p. 236-243, 1988. 
DEATON, A. Panel data from time series of cross-sections. Journal of Econometrics, v. 30, p. 109126, 1985.

GREENE, W. H. Econometric analysis. 4. ed. New Jersey: Prentice Hall; Englewood Cliffs, 2000.

HAUSMAN, J. A. Specification tests in econometrics. Econometrica, v. 46, p. 1251-71, 1978.

HSIAO, C. Analysis of panel data. Econometric Society Monographs, n. 11, 1986

HUANG, W. R. Gender differences in the earnings of lawyers. Columbia Journal of Law and Social Problems, v. 30, p. 267-325, 1997.

KASSOUF, A. L. Wage gender discrimination and segmentation in the Brazilian labor market. Economia Aplicada, São Paulo, v. 2, n. 2, p. 243-269, 1998.

INTERNATIONAL LABOUR ORGANIZATION. World Employment Report 2001 : life at work in the information economy., Geneva, Switzerland: International Labour Force, 2001. Compact Disc available at Ministry of National Planning Office.

LABAND, D. N.; LENTZ, B. F. Is there sex discrimination in the legal profession? Journal of Human Resources, v. 28, p. 230-258, 1993.

LEME, M. C. S.; WAJNMAN, S. Tendências de coorte nos diferenciais de rendimentos por sexo. In: HENRIQUES, R. (Org.). Desigualdade e pobreza no Brasil. Brasília, DF: IPEA, 2000. Cap. 9.

LOUREIRO, P. R. A. Uma resenha teórica e empírica sobre economia da discriminação. Revista Brasileira de Economia, v. 57, n. 1, p. 125-157, 2003.

NEGRI, J. A. et al. Mercado formal de trabalho: comparação entre microdados da RAIS e da PNAD. Rio de Janeiro: IPEA, 2001. (Texto para Discussão, n. 840).

NEUMARK, D. Labor market information and wage differentials, by race and sex. Cambridge, MA: NBER, 1998. (NBER Working Paper, n. 6573).

OAXACA, R. Male-female wage differentials in urban labor markets. International Economic Review, v. 14, p. 693-709, 1973.

OAXACA, R.; RANSOM, M. R. On discrimination and the decomposition of wage differentials. Journal of Econometrics, v. 61, p. 5-21, 1994.

. Identification in detailed wage decompositions. Review of Economics and Statistics, v. 81, p. 154-157, 1999.

OMETTO, A. M.; HOFFMAN, R.; ALVES, M. C. Participação da mulher no mercado de trabalho: discriminação em Pernambuco e São Paulo. Revista Brasileira de Economia, v. 53, n. 3, p. 287-322, 1999.

PASHIGIAN, B. P. The market for layer: determinants of the demand for and supply for lawyers. The Journal of Law and Economics, v. 20, p. 53-85, 1977.

PHELPS, E. S. The statistical theory of racism and sexism. American Economic Review, v. 62, p. 659-661, 1972. 
ROSEN, S. The Market for lawyers. Journal of Law 8 Economics, v. 35, n.2, p. 215-236, Oct. 1992.

SABOIA, J. L. M.; TOLIPAN, R. M. L. A relação anual de informações sociais (RAIS) e o mercado formal de trabalho no Brasil: uma nota. Pesquisa e Planejamento Econômico, v. 15, n. 2 , p. 447-456, ago. 1985.

SAUER, R. M. Job mobility and the market for lawyers. Journal of Political Economy, v. 106, p. 147-171, Feb. 1998.

SPURR, S. J. Sex discrimination in the legal profession: a study of the promotion. Industrial and Labor Relations Review, v. 43, n. 4, p. 406-415, Apr. 1990.

STAGER, D. A. A.; FOOT, D. K. Lawyer's earnings under market growth and differentiation, 1970-1980. The Canadian Journal of Economics, p. 150-163, Feb. 1989a.

STAGER, D.A.A.; FOOT, D. K. Intertemporal market effect on gender earnings differentials: lawyers in Canada, 1978-1980. Applied Economics, v. 21, n. 8, p. 1011-1028, 1989b.

WOOD, R. G.; CORCORAN, M. E.; COURANT, P. N. Pay differences among the highly paid: the male-female earnings gap in salaries. Journal of Labor Economics, Chicago, v. 11, n. 3, p. 417441, Jul. 1993.

Recebido em: 03/11/2008. Aceito em: 30/05/2010. 